\title{
Interactive comment on "A distributed simple dynamical systems approach (dS2 v1.0) for computationally efficient hydrological modelling" by Joost Buitink et al.
}

\section{Anonymous Referee \#1}

Received and published: 16 August 2019

Dear authors, thank you for submitting your paper. In the following, you will find my comments, suggestions, and opinion of your contribution.

\section{Summary}

The paper "A distributed simple dynamical systems approach (dS2 v1.0) for computationally efficient hydrological modelling" is about a distributed hydrological modelling based on the simple dynamical system approach, SDS (Kirchner, 2009). The model is grid-based (cell of $1 \mathrm{~km} 2$ ) and enables rainfall-runoff simulations for mesoscale basins (up to $2000 \mathrm{~km} 2$ ) at high temporal and spatial resolution with a new 3-parameter discharge sensitivity function. The model is first developed and assessed for synthetic

Printer-friendly version

Discussion paper 
experiment and then applied to the alpine Thur catchment (1700 km2). Authors used Monte-Carlo methodology to generate model parameter sets constrained within the synthetic parameter ranges. The model is complemented with snow and routing modules to take into account the lag-time.

\section{General comments}

The manuscript is clearly written but has in its present form some major defaults. The authors put forward the novelty of the proposed approach. This is not right since the approach is not unique in its formulation. What is proposed is a simple dynamical system approach by Kirchner applied in its distributed form. Such model, however already exists (please check Adamovic et al. 2016, Journal of Hydrology). The latter was not cited in this article. Adamovic et al. (2016) implemented the SDS approach on Ardeche catchment (around $2400 \mathrm{~km} 2$ ) and developed the model called SIMPLEFLOOD that is computationally fast and coupled with a kinematic wave flow propagation module.

\section{Specific comments}

Here are, however, my short comments that I think can contribute to its better content once reformulating and updating the article.

\section{Page 2. Line: 25}

The authors mention continental-scale forcing datasets in relation with merged radar data, interpolated station data, and atmospheric reanalysis. It would be valuable for readers if they know in more details about actual spatial but also temporal scales of provided references.

Page 2. Line: 35

The phrase "An efficient distributed conceptual model to tackle these kinds of issues is currently lacking." is not correct. Adamovic et al. (JoH, 2016) already developed this approach at an hourly time step and applied it to the Ardeche catchment.

Printer-friendly version

Discussion paper 
Page 3. Line: 25

Similar to the previous comment. The approach was already applied to the mesoscale catchment of $2400 \mathrm{~km} 2$ (Adamovic et al., 2016).

Page 6. Line: 15

The introduction of a third parameter that avoids having a curvature that diverges computations is interesting even though it has its limitations since it seems that three parameters depend on each other.

\section{Page 8. Flow routing}

Authors introduced simplified routing module that is not explicit but rather based on a simple temporal delay to the outlet. More sophisticated flow routing module is described in Adamovic et al. (2016) which takes into account the feedback effects.

\section{Page 12. Closure of the water balance}

In the model, the water balance seems closed only in conditions when AET=PET (humid conditions). If the model is to be applied on pan-European scales with different conditions, the question about the AET estimation should be addressed.

Page 13. Parameter sensitivity

It would be useful for a reader to know what the realistic parameter ranges are and how did you choose them since you applied the method on the synthetic catchment in this section.

\section{Page 16. Example application}

Line: 23. Did you also run the MC analysis with the fewer or higher number of iterations? Why did you choose 25000 ? Many authors used fewer iterations for higher-order parametric models (e.g. Tekleab et al. 2011).

Printer-friendly version

Discussion paper

Page 17. Line: 7 
"Parameter set that performer best for the event". Is it the one that showed the highest KGE? If it is the case, what was the value?

\section{Page 17. Line: 9}

"...the timing of the peak is well simulated in all three basins". It seems that for the Andelfingen catchment (Fig. 10e), there is a peak delay of around $6 \mathrm{~h}$ between the observation and simulation for this specific event. I would suggest reformulating this sentence and discussing what could be a reason for such peak delay since it is the largest explored catchment. Could it be that the simplified routing module shows the lack of performance in this case? Testing it in more catchments could give a more robust answer.

Technical corrections

Figure 1.

Panels in capitals A, B, C instead of small letters. This will improve the text visibility.

Figure 10 a.

I would suggest colouring the catchments for better visibility.

Figure $10 \mathrm{~b}, \mathrm{c}$ and $\mathrm{d}$.

I would suggest plotting these figures on a log-scale for better visibility and assessing the influence of evapotranspiration.

Figure 10.e

I would suggest not using the light colours for observations since it is not well readable (i.e. Mogelsberg catchment). Asterix or other dash types could be more appropriate in this case.

\section{References}

Adamovic, M., Branger, F., Braud, I., Kralisch, S., 2016. Development of 
a data-driven semi-distributed hydrological model for regional scale catchments prone to Mediterranean flash floods. Journal of Hydrology, 541: 173-189. DOI:https://doi.org/10.1016/j.jhydrol.2016.03.032

Tekleab, S., Uhlenbrook, S., Mohamed, Y., Savenije, H. H. G., Temesgen, M., and Wenninger, J.: Water balance modeling of Upper Blue Nile catchments using a topdown approach, Hydrol. Earth Syst. Sci., 15, 2179-2193, doi:10.5194/hess-15-21792011, 2011.

Interactive comment on Geosci. Model Dev. Discuss., https://doi.org/10.5194/gmd-2019-150, 2019. 